\title{
CYTOKINE-LIKE SUBSTANCE: ORIGIN AND FATE IN CHAGAS'DISEASE A NEW HYPOTHESIS ABOUT THE LOCAL INFLAMMATORY REACTION ETIOPATHOGENESIS (experimental study in white mice)
}

\author{
Masayuki Okumura, Pedro Luiz S. Pinto, Roberto Takami, Elizabeth \\ V. Nunes, Carmem S. Guilherme, Oswaldo Cruz Oliveira Júnior, \\ Joaquim J. Gama-Rodrigues and Kiyoshi Iriya
}

RHCFAP/2965

OKUMURA, M. et al. - Cytokine-like substance: origin and fate in Chagas'disease. A new hypothesis regarding the etiopathogenesis of its local inflammatory reaction (experimental study in white mice). Rev Hosp Clín Fac Med S Paulo, 54 (3): 73 - 74, 1999

DESCRIPTORS : Chagas'disease. Citokine-like.

The authors began the study of cytokines or the so-called plasma activators of the acute inflammatory reaction in infections in September 1997.

As far back as with the origina report describing the Chagas' Disease (CD), Carlos Chagas $(1911)^{3,4}$, Gaspar Vianna (1911) $)^{15}$ and Okumura $(1967)^{11}$ interpreted the etiopathogenesis of the Chagas' Disease as follows.

The first event is the invasion of the host cell by the trypomastigote form of the Trypanosoma cruzi (Chagas 1909)2. The flagellum becomes disconnected from the parasite and the trypomastigotes change into the amastigote form. The amastigotes multiply by successive binary fission clustering together to form a compact nest of parasites inside the host cell. The parasites subsequently evolve to the epi- and trypomastigote flagellate forms releasing their cellular content into the nest fluid. These flagellate forms move actively in the nest fluid, provoking the rupture of the amastigote nest and consequently host cell injury. Lastly, the epi and trypomastigote forms gain access the interstitial space.

These authors ${ }^{3,11,15}$ stressed the fact that absolutely no inflammatory changes surrounding the unruptured nest were recorded as long as the amastigote nests remained intact or at the time of the nest rupture. Amastigote cell nest rupture releases several chemical factors produced by the distinct evolutionary stages of the parasite, that is, the trypo, epi, and amastigote forms. These chemical factors are metabolic and degradation products, namely, proteins, lipids, carbohydrates, RNA and DNA fractions,

From Department of Gastroenterology "Hospital das Clínicas" and Dep. Pathology - "Faculdade de Medicina da Universidade de São Paulo, Instituto de Medicina Tropical de São Paulo" and "Instituto Adolfo Lutz de São Paulo". cytoplasmic, and cell membrane particles $^{11,12,13}$.

The authors' objectives in this experiment were to study the formation and the action of these factors in experimental Chagas' Disease.

The description of several factors in the 70's, namely, lymphocyte activating factor by Gery \& Waksman? the leucocytic endogenous mediator by Merriman et al. ${ }^{9}$, and the cytokines by Dinarello in $1984^{6}$ who described " the activators of immunity in defense of the host", led us to believe that a familiar substance participates actively in the etiopathogenesis of the experimental Chagas'Disease. (Figs. $1,2,3,4)$.

Using cytokine markers, we observed that while the mastigote nest remains intact or at the moment of nest rupture, no cytokine markers are detected. However, the interstitial cell space becomes stained brown or chestnut brown immediately after the acute inflammatory reaction is in pro- 


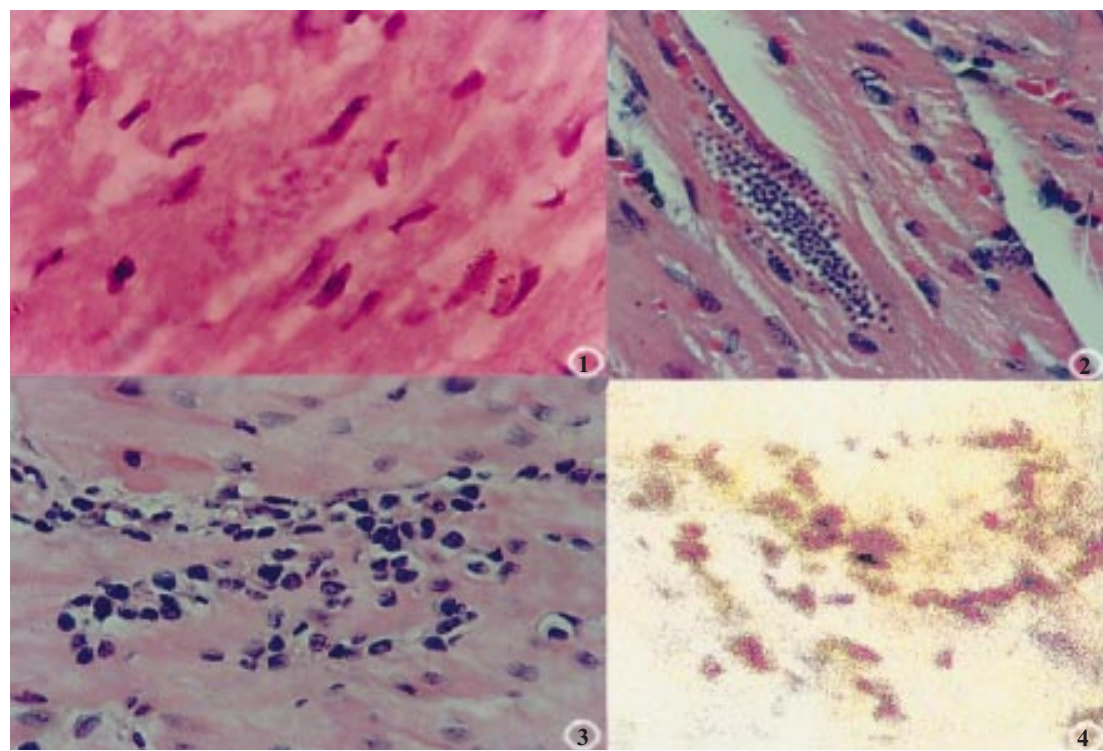

Figures 1-4 - 1. Heart integral amastigotes nest: Absence of acute inflammatory reaction. 2. Heart: rupture of nest with liberation of amastigotes in the myocardial fiber, without inflammatory reaction. Interstitial edema. 3. Heart: parasites and acute inflammatory reaction. 4. "Cytokines" stained in chestnutbrown in the interstitial space with acute inflammatory reaction - presence of WBCs at site.

gress $^{5}$. This observation led us to admit that a specific factor; a procytokine is released by the parasite. The procytokine reacts with another procytokine from the host, forming a substance, that the authors herein refer as cytokine-like. The latter activates the circulating white blood cells (WBCs: polymorphonuclear, basophils, monocytes, and "naive" lymphocytes) through the local vessels in the amastigote nest rupture site. Alternatively, the cytokine-like factor enters the blood stream and the hematopoietic system is activated, and as well as the cellular mediators of the acute inflammatory reaction that are drawn to the rupture site, initiating an acute inflammatory reaction. In other words, the cytokine-like substance, which is stained by the cytokine marker, appears to be present in the interstitial space immediately after rupture of the nest, before the arrival of the white blood cells that produce the inflammatory response.

The interpretation of this information led us to suppose that the macrophages and lymphocytes ${ }^{8}$ do not produce or release cytokines ${ }^{4,7}$ as many authors have believed to this date ${ }^{10}$. Alternatively, we believe that the cytokine is activated first, which in turn activates the lymphocytes and macrophages, which are not stained by the cytokine-marker, since they do not produce the cytokine.

\section{REFERENCE}

1. ABBAS, A.K; LICHTMAN, A H and POBER, J.S. Cellular and Molecular Immunology. 3th ed. Philadelphia, Saunders, 1997.

2. CHAGAS C - Nova tripanozomíase humana; estudo sobre a morfologia e o ciclo evolutivo do Schizotrypanum cruzi n. gen. n. sp., agente etiológico de nova entidade mórbida do homem. Mem Inst Oswaldo Cruz 1909; 1:59.218

3. CHAGAS C - Nova entidade mórbida do homem. Resumo geral de estudos etiológicos e clínico. Mem Inst Oswaldo Cruz, 1911; 3:3-59.

4. CHAGAS C - Tripanosomíase americana. Forma aguda da moléstia. Mem Inst Oswaldo Cruz 1916; 8:37-60.

5. CORBETT CEP et al. - Cytokines and Chagas disease in mice. Rev Hosp Clín Fac Med S Paulo 1998; 53:01-02.

6. DINARELLO CA - Interleukin-1, Molecular basis of the immune response. Ann N Y Acad Sci 1988; 546:122-132.

7. GERY I \& WAKSMAN, BH - Potentiation of the T. lymphocyte response to mitogen. II. The cellular source of potentiating mediator(s). 136 J Exp Med 1972; 136:143-155.

8. KINASHI T, INABA K, TSUBATA $\mathrm{T}$ et al. - Differentiation of a Precursor Cell with the Germline Context of Immunoglobulin Gene into Immunoglobulin-Producing Cells in Vitro. Molecular Basis of the Immune Response. Ann N Y Acad Sci 1988; 546:1-8.
9. MERRIMAN CR, PULLIAM L A \& KAMPSCHMIDT RF Comparison of leukocytic pyrogen and leucocytic mediator. Proc Soc Exp Biol Med 1977; 154:224-227.

10. MIRE-SLUIS, A. R. \& THORPE, R. - Citokines. San Diego, Acad. Press, 1998.

11. OKUMURA M - Contribuição para o estudo das lesões dos neurônios do pleso mientérico do colo na moléstia de Chagas experimental no camundongo branco (Mus musculus, L.). Rev Hosp Clín Fac Med S Paulo 1967; 22:192-203.

12. OKUMURA M - Chagasic megacolon. In: WORLD CONGRESS OF THE INTERNATIONAL COLLEGE OF SURGEONS, 19th. Proceeding. Lima, Perú, 1974. v.3, p. 1931.

13. OKUMURA M - Pathogenesis of chagasic myocarditis (an experimental study). Rev Hosp Clín Fac Med S Paulo 1996; 51:166174.

14. OKUMURA M - My conception of cytokine (In experimental Chagas'disease). Rev Hosp Clín Fac Med S Paulo 1998; 53:1.

15. VIANNA G - Contribuição para o estudo da anatomia patológica da "moléstia de Carlos Chagas". Mem Inst Oswaldo Cruz 1911; 3:276.294.

Received for publication on the 09/04/99 